\title{
PRODUCTIVE AND REPRODUCTIVE PERFORMANCE OF MAGHREBI SHE- CAMELS FED WITH ORGANIC ZINC DIET UNDER SEMI-ARID EGYPTIAN CONDITIONS
}

\author{
Sabrin A. Morshedy ${ }^{1 *}$, E. Mohamed ${ }^{2}$, Y.M. El-Gindy ${ }^{1}$, T.H. Mostafa ${ }^{2}$, S.M. Zahran ${ }^{1}$ and \\ M.H. Ahmed ${ }^{1}$ \\ ${ }^{1}$ Fish and Animal Production Department, Faculty of Agriculture Saba Basha, Alexandria University, \\ 21531, Alexandria, Egypt. \\ ${ }^{2}$ Camel Research Department, Animal Production Research Institute, Dokki, Giza, Egypt. \\ *Correspondence: E-mail : sabrin_morshedy@alexu.edu.eg
}

(Received 30/12/2019, accepted 2/2/2020)

\section{SUMMARY}

$\mathrm{O}$ rganic zinc-binding with probiotic (Biogen- $\mathrm{Zn}^{\circledR}$; BZ) is a $\mathrm{Zn}$-methionine combined with Bacillus subtilis capable of improving zinc bioavailability, animal health and ameliorating reproductive stress. The present experiment was performed to evaluate the effect of addition BZ to she-camels on their physiological status, reproductive and productive traits under semi-arid Egyptian conditions. Twenty pregnant Maghrebi camels (4-6 parities) with average body weight of $519.96 \pm 19.98 \mathrm{~kg}$ were randomly divided into four groups ( $\mathrm{n}=5$ in each) according to live body weight and parity. The $1^{\text {st }}$ group, camels were fed basal ration and served as control (without supplementation). The $2^{\text {nd }}, 3^{\text {rd }}$ and $4^{\text {th }}$ groups of camels were fed the basal ration supplied with BZ at doses of 5, 7, and $10 \mathrm{~g} \mathrm{BZ/head/day,} \mathrm{respectively.} \mathrm{BZ} \mathrm{was} \mathrm{added} \mathrm{daily} \mathrm{during} \mathrm{a} \mathrm{period} \mathrm{from}$ the first day of the $10^{\text {th }}$ month of pregnancy period and continued up to seven months of lactation period. Blood samples were collected biweekly during different she-camels' reproductive stages at $10^{\text {th }}$ monthly of pregnancy, at $1^{\text {st }}$ day after calving, and during seven months of lactation period. The results indicated that BZ significantly increased glucose concentrations in serum, total protein, globulin in dose dependent manner. While, serum concentrations of cholesterol, triglycerides, low density lipoprotein and very low-density lipoprotein were decreased in treated groups compared to the control one. Liver and kidney functions were improved at different sampling stages with $10 \mathrm{~g}$ of BZ treatment. Moreover, camels treated with $10 \mathrm{~g}$ of BZ revealed a significant effect on placental characteristics fluids including, the shortest duration drop of placenta and the heaviest weights of placenta treated group. As well as, live body weight at $1^{\text {st }}$ service,-number of services/conception and service period length during the post-partum period were improved by BZ supplementation. In conclusion, organic zincbinding with probiotic (BZ) has a potential use for improving physiological status, reproductive and productive performance of she-camels, to particularly with a dose of $10 \mathrm{~g} / \mathrm{h} / \mathrm{d}$ of BZ.

Keywords: Organic zinc, blood constituents, productive, reproductive performance and she-camels.

\section{INTRODUCTION}

No doubt that the pre-parturition period, means the transition period from late pregnancy to early lactation is the most important stage of the lactation cycle. It is noteworthy that female animals' difficulties traverse changing from the pregnant, non-lactating state to the non-pregnant, lactating state (Goff and Horst, 1997). Oxidative stress is generated during normal placental development and become exaggerated when the supply of antioxidant micronutrients is limited, resulting in a negative effects on pregnancy outcome (Mistry and Williams, 2011). Moreover, two factors were conflicted together and contributed to the development of complications in late pregnancy; the first factor is energy imbalance which generates oxidative stress and increase lipid peroxidation and the second is lack of antioxidant activity (Bernabucci et al., 2002). The health problems could be continued after birth resulted from poor nutritional management immediately after calving (Bell, 1995).

Therefore, transition period needs more attentions as management, nutrition and health care. Thus, nutrition and management of camels during the transition period have received tremendous interest lately. In 
this concern, a number of micronutrients act as essential cofactors or as antioxidants. Especially, trace minerals have an positive effect to provide sufficient amounts for the developing fetus and defender from the risk of stress periods (Larson 2005).

One of such minerals, zinc $(\mathrm{Zn})$ is an essential element required by ruminants for several biochemical functions. Zinc plays important roles in improvement growth and health in animals as it needed for energy and protein metabolism (NRC, 2001). Also, Soetan et al. (2010) reported that the need Zn for majoity animals based on its influence on activities of enzymes and proteins. Whereas, these enzymes and proteins affect vitamin A synthesis, carbon dioxide transport, collagen fiber degradation, free radical destruction, red blood cells membrane stability and metabolism of fatty acids, carbohydrate, protein and nucleic acids. Moreover, Zn demands for skin integrity, cell repair, development of the immune response and neurological function (Haase and Rink, 2014). Patel et al. (2017) also reported that supplementation of 80 and $120 \mathrm{ppm}$ $\mathrm{Zn}$ in feed during pre-partum period to cows is effective in improving post-partum reproductive performance.

Trace elements connected with specific amino acids makes are bioavailable and have better retention than the inorganic source, (Pari-patananont and Lovell, 1997 and Nockels et al., 1993). Zinc-methionine (Zn-Met) is unaffected by rumen microbes and absorbed to a similar amount as Zn oxide, but Zn-Met appears to be metabolized inversely after absorption with lower urinary excretion and a slower rate of decline in plasma $\mathrm{Zn}$ (Spears, 1989). Furthermore, organic Zn supplementation can enhance resistance to udder stress in dairy goats (Salama et al., 2003). Mostafa et al. (2019) revealed that addition Zn-Met at a level of $50 \mathrm{mg} / \mathrm{kg}$ DM 3 month's pre-partum up to 9 months post-partum, improved milk production, reproductive performance of female camels and growth performance of their offspring.

Furthermore, in terms of mixed zinc methionine with Bacillus subtilis (Biogen-Zn ${ }^{\circledR}$ ), Abu El-Ella et al. (2014) confirmed that addition of BZ as 0.5 or $1.0 \mathrm{~g} / \mathrm{h}$ ead/day during reproduction stages of goats able to improve reproductive performance through lowering the incidence of estrus, reducing the number of days to estrus, conception rate, fertility, fecundity and kidding rate and improve some blood components. Therefore, the current study aimed to evaluate the effect of Biogen- $\mathrm{Zn}^{\circledR}$ supplementation on productive, reproductive and blood biochemical constituents of she-camels throughout the different stages of reproduction including late pregnancy, at calving, post-calving and the continues to seven months of lactation.

\section{MATERIALS AND METHODS}

\section{Animals and feeding management:}

The experimental part of this study was carried out at Center of Studies and Development of Camel Production, belonging to Animal Production Research Institute, Agricultural Research Center, Matrouh Governorate- Egypt, during the period from April, 2018 to April, 2019. Determinations of serum constituents were performed at the laboratory belonging to Animal and Fish Production Department, Faculty of Agriculture (Saba Basha), Alexandria University, Egypt.

Twenty pregnant Maghrebi camels (4-6 parities) with average live body weight $519.96 \pm 19.98 \mathrm{~kg}$ were randomly divided into four groups $\left(\mathrm{n}=5\right.$ in each) according to live body weight and parity. The $1^{\text {st }}$ group, camels were fed the basal ration and served as control (without supplementation). The $2^{\text {nd }}, 3^{\text {rd }}$ and $4^{\text {th }}$ groups, camels were fed the basal ration supplemented with Biogen- $\mathrm{Zn}^{\circledR}$ at doses of 5,7 , and $10 \mathrm{~g} \mathrm{BZ} / \mathrm{head} / \mathrm{day}$, respectively. BZ supplementation was started feed at the beginning of the $10^{\text {th }}$ month of pregnancy period and continued up to the seven months of lactation period.

The basal ration was composed of $40 \%$ concentrate feed mixture (CFM), $30 \%$ berseem hay (BH), and $30 \%$ rice straw (RS). The camels were separately fed according to the recommendation of the Animal Production Research Institute, which meets maintenance, pregnancy, and milk production requirements. The specific feed amounts were about 3-4 kg CFM, 2-3 kg BH, and 2-3 kg RS /camel/day. The ration was offered twice daily during the trial period. The composition of CFM was soybean meal (44\% CP, $80.00 \mathrm{~g}$ ), corn yellow $250.00 \mathrm{~g}$, barley $280.00 \mathrm{~g}$, wheat bran $320.00 \mathrm{~g}$, molasses $35.00 \mathrm{~g}$, limestone $20.00 \mathrm{~g}$, sodium chloride $13.0 \mathrm{~g}$, vit.-min. premix $2.00 \mathrm{~g}$. and the procimate analysis of CFM was $126 \mathrm{~g}$ crude protein and 233 $\mathrm{g}$ crud fiber. Water was delivered to camels ad libitum in water racks. 


\section{Serum biochemical constituents:}

Blood samples were collected biweekly during different she-camels' reproductive stages, at the $10^{\text {th }}$ month of the pregnancy period, at $1^{\text {st }}$ day after calving, and every month during seven months of lactation period. Blood samples were collected from Jugular vein puncture without anticoagulant into plain test-tubes. Collected blood samples were centrifuged ( $3000 \mathrm{rpm}, 15 \mathrm{~min}$.) and the serum was carefully decanted into serum vials. Serum samples were stored in deep freezer $\left(-20^{\circ} \mathrm{C}\right)$ until being used for biochemical analysis.

The serum glucose, total protein and albumin Globulin concentration was calculated by the difference between total protein and albumin, cholesterol and triglycerides (TG) High-density lipoprotein-cholesterol (HDL) Low-density lipoprotein-cholesterol (LDL) was calculated according to Warnick et al. (1983) by the formula:

$$
\mathrm{LDL}=\text { cholesterol }(\mathrm{HDL}+\mathrm{VLDL}) .
$$

Very low-density lipoprotein-cholesterol (vLDL) was calculated by dividing the values of TG by factor of 5 according to Warnick et al. (1983). Serum blood urea nitrogen (BUN, mg/dl), Creatinine, $\mathrm{mg} / \mathrm{dl}$, the activities of serum aspartate-aminotransferase (AST), alanine-aminotransferase (ALT), Alkaline phosphatase (ALP) activity, all determination were executed according to the colorimetrically determined by using commercial kits produced by Bio Diagnostic, Egypt.

\section{Reproductive parameters:}

Determinations of LBW at first service (kg), No. of services/ conception, service period length (day), conception rate (\%, number of pregnant camels divided by inseminated camels), gestation period (day), placental drop $(\mathrm{min})$, placental weight with fluids $(\mathrm{kg})$ and placenta weight without fluids $(\mathrm{kg})$ were recorded.

\section{Body weight and feed intake:}

Camels in all groups were individually weighed at the beginning of the experiment (at the $10^{\text {th }}$ month of pregnancy), after $1^{\text {st }}$ calving, after that they were monthly weighed for 7 months. The consumed amount of $\mathrm{CFM}, \mathrm{BH}$, and SR were separately recorded during the whole experiment.

\section{Statistical analysis:}

Data were statistically analyzed using the General Linear Model procedure of the Statistical Analysis System (SAS, 2001). Data obtained were tested by analysis of variance with one-way design to test the treatment group differences at each sampling time during pre-, post-partum and 7 lactation months according to the following model:

$$
\mathrm{Y}_{\mathrm{ij}}=\mu+\mathrm{P}_{\mathrm{i}}+\mathrm{e}_{\mathrm{ij}}
$$

where: $\mathrm{Y}_{\mathrm{ij}}=$ observed values; $\mu=$ overall mean; $\mathrm{P}_{\mathrm{i}}=$ trail group; $\mathrm{e}_{\mathrm{ij}}=$ random error.

Values were given as mean. The significant differences among groups were detected to Duncan's multiple range test (Duncan, 1955).

\section{RESULTS AND DISCUSSION}

\section{Biochemical traits:}

Effects of addition she-camels with different levels of BZ (5, 7, and $10 \mathrm{~g} \mathrm{BZ} / \mathrm{h} / \mathrm{d})$ on serum glucose concentration and protein profile are presented in Table (1). Results showed that supplementation BZ at different levels caused significant or numerical increases in serum glucose concentration at $10^{\text {th }}$ month of pregnancy and $1^{\text {st }}$ month of post-partum compared with control group. Meanwhile, it is clearly to note that addition of $10 \mathrm{~g} \mathrm{BZ/h/d} \mathrm{significantly} \mathrm{or} \mathrm{numerically} \mathrm{increased} \mathrm{serum} \mathrm{glucose} \mathrm{at} \mathrm{first} \mathrm{day} \mathrm{after} \mathrm{calving} \mathrm{and}$ during lactation period as compared with the other treated and control groups. Zeedan et al. (2014) Plasma glucose was significantly increased $(\mathrm{P}<0.05)$ with supplementing BZ within the two stages (late pregnancy and Lactation of sheep). The mechanism by which probiotic increased serum glucose could be attributed to increasing cellulolytic bacteria that act on cellulose fibers degradation and produce more glucose; increase the glucogenic precursor propionate in rumen, decrease plasma insulin and insulin-glucose ratio, indicating 
an increase in gluconeogenesis. These results concurred with Zeedan et al. (2008 and 2009a) who reported that addition BZ in sheep rations caused an increase in serum glucose during different physiological stages. Also, Abu El-Ella et al. (2014) indicated that feeding Damascus goats does on diets containing two levels of $\mathrm{BZ}(0.5$ and $1.0 \mathrm{~g} / \mathrm{h} / \mathrm{d})$ led to increase $(\mathrm{P}<0.05)$ glucose level during pregnancy and lactation periods.

Table (1): Blood serum glucose, protein profile (mg/dl) and albumin/globulin ratio of she-camels ration including different levels of Biogen- $\mathrm{Zn}^{\circledR}$.

\begin{tabular}{|c|c|c|c|c|c|c|}
\hline \multirow{2}{*}{ Item } & \multicolumn{4}{|c|}{ Biogen-Zn ${ }^{\circledR}$ level (g/head/day) } & \multirow{2}{*}{ SEM } & \multirow{2}{*}{$P$ value } \\
\hline & 0 & 5 & 7 & 10 & & \\
\hline \multicolumn{7}{|c|}{ Glucose } \\
\hline $10^{\text {th }}$ month of pregnancy & $60.27^{\mathrm{b}}$ & $107.09^{\mathrm{a}}$ & $111.89^{\mathrm{a}}$ & $112.85^{\mathrm{a}}$ & 3.162 & 0.0001 \\
\hline $1^{\text {st }}$ day after calving & $96.95^{\mathrm{b}}$ & $104.96^{\mathrm{b}}$ & $099.04^{\mathrm{b}}$ & $109.87^{\mathrm{a}}$ & 2.196 & 0.0141 \\
\hline $1^{\text {st }}$ month post-partum & $85.60^{\mathrm{b}}$ & $095.84^{\mathrm{a}}$ & $100.95^{\mathrm{a}}$ & $102.73^{\mathrm{a}}$ & 3.050 & 0.0089 \\
\hline During lactation period & $89.03^{\mathrm{b}}$ & $092.65^{\mathrm{b}}$ & $092.15^{\mathrm{b}}$ & $100.08^{\mathrm{a}}$ & 1.291 & 0.0031 \\
\hline \multicolumn{7}{|c|}{ Total protein } \\
\hline $10^{\text {th }}$ month of pregnancy & 7.17 & 7.14 & 7.37 & 7.05 & 0.15 & 0.6191 \\
\hline $1^{\text {st }}$ day after calving & $7.12^{\mathrm{b}}$ & $8.07^{\mathrm{a}}$ & $7.53^{\mathrm{b}}$ & $7.39^{b}$ & 0.13 & 0.0020 \\
\hline $1^{\text {st }}$ month post-partum & $6.91^{\mathrm{b}}$ & $7.77^{\mathrm{a}}$ & $7.46^{\mathrm{ab}}$ & $7.64^{\mathrm{ab}}$ & 0.22 & 0.0455 \\
\hline During lactation period & $7.06^{\mathrm{b}}$ & $7.45^{\mathrm{ab}}$ & $7.75^{\mathrm{a}}$ & $7.95^{\mathrm{a}}$ & 0.18 & 0.0265 \\
\hline \multicolumn{7}{|c|}{ Albumin } \\
\hline $10^{\text {th }}$ month of pregnancy & 3.59 & 3.73 & 3.64 & 3.55 & 0.14 & 0.8258 \\
\hline $1^{\text {st }}$ day after calving & 3.88 & 3.72 & 3.58 & 3.47 & 0.16 & 0.3804 \\
\hline $1^{\text {st }}$ month post-partum & 3.91 & 3.47 & 3.57 & 3.24 & 0.19 & 0.1799 \\
\hline During lactation period & 3.62 & 3.75 & 3.70 & 3.46 & 0.18 & 0.6954 \\
\hline \multicolumn{7}{|c|}{ Globulin } \\
\hline $10^{\text {th }}$ month of pregnancy & 3.58 & 3.41 & 3.73 & 3.50 & 0.21 & 0.8109 \\
\hline $1^{\text {st }}$ day after calving & $3.25^{\mathrm{b}}$ & $4.35^{\mathrm{a}}$ & $3.95^{\mathrm{ab}}$ & $3.92^{\mathrm{ab}}$ & 0.22 & 0.0384 \\
\hline $1^{\text {st }}$ month post-partum & $3.00^{\mathrm{b}}$ & $4.30^{\mathrm{a}}$ & $3.89^{\mathrm{ab}}$ & $4.39^{\mathrm{a}}$ & 0.30 & 0.0316 \\
\hline During lactation period & 3.44 & 3.70 & 4.05 & 4.49 & 0.27 & 0.1009 \\
\hline \multicolumn{7}{|c|}{$\mathrm{A} / \mathrm{G}$ ratio } \\
\hline $10^{\text {th }}$ month of pregnancy & 1.00 & 1.09 & 0.98 & 1.01 & 0.09 & 0.7859 \\
\hline $1^{\text {st }}$ day after calving & 1.19 & 0.86 & 0.91 & 0.89 & 0.06 & 0.0817 \\
\hline $1^{\text {st }}$ month post-partum & $1.30^{\mathrm{a}}$ & $0.81^{b}$ & $0.92^{b}$ & $0.74^{\mathrm{b}}$ & 0.10 & 0.0012 \\
\hline During lactation period & 1.05 & 1.01 & 0.91 & 0.77 & 0.11 & 0.0915 \\
\hline
\end{tabular}

Means in the same row not sharing the same superscript differ significantly.

The present findings indicating that serum total protein concentration of she-camels was significantly $(\mathrm{P}<0.05)$ higher by adding $5 \mathrm{~g} \mathrm{BZ/h/d}$ at $1^{\text {st }}$ day after calving and at $1^{\text {st }}$ month post-partum as compared with the other groups and control. However, camels received 7 and $10 \mathrm{~g}$ of $\mathrm{BZ} / \mathrm{h} / \mathrm{d}(\mathrm{P}<0.05)$ increased TP followed by those animal fed ration including $5 \mathrm{~g}$ BZ during lactation period as compared with the control groups.

Effects of addition she-camels with different levels of BZ (5, 7, and $10 \mathrm{~g} \mathrm{BZ} / \mathrm{h} / \mathrm{d})$ did not significantly $(\mathrm{P}>0.05)$ change on serum albumin concentration.

At $1^{\text {st }}$ day after calving and throughout the $1^{\text {st }}$ month post-partum addition of $5 \mathrm{~g} \mathrm{BZ} / \mathrm{h} / \mathrm{d}$ significantly $(\mathrm{P}<0.05)$ increased serum globulin in comparison with the control group. Furthermore, addition of $10 \mathrm{~g}$ $\mathrm{BZ} / \mathrm{h} / \mathrm{d}$ significantly $(\mathrm{P}<0.05)$ increased serum globulin at $1^{\text {st }}$ month post-partum in comparison with the control group. However, albumin/ globulin ratio didn't affect by addition she-camels with different levels of BZ $10^{\text {th }}$ month of pregnancy, $1^{\text {st }}$ day after calving and during lactation periods of camels. However, at $1^{\text {st }}$ month post-partum, A/G ratio significantly $(\mathrm{P}<0.05)$ decreased by addition different levels of BZ compared to the control group. Our results was proven early by Seleim et al. (2003) who reported that TP, AL and GL were in normal values $(7.60,3.3$ and $4.32 \mathrm{mg} / \mathrm{dl}$ ), respectively in 2-12-years old of Egyptian camels. Also, the present results were in accordance with those obtained by Shams (2008) and Zeedan et al. (2008 and 
2009b) who found that addition Zn-Met or BZ improved blood globulin compared to the control group. Recently Mostafa et al. (2019) found that TP and AL were $(\mathrm{P}<0.05)$ higher in camels fed ration containing $50 \mathrm{mg}$ Zn-Met during pre-partum than control group, as well as, the concentration of TP was $(\mathrm{P}<0.05)$ increased with high doses of $\mathrm{Zn}$-Met (40 and $50 \mathrm{mg}$ ) during post-partum as compared with the control and those of camel received low dose of Zn-Met (30 mg).

In conflict to the present results, Abd El-Hamid et al. (2019) found that serum TP, AL and GL levels didn't $(\mathrm{P}>0.05)$ differ by the supplementation of $2.7 \mathrm{~g} / \mathrm{h} / \mathrm{d}$ of trace elements $(\mathrm{Cu}, \mathrm{Zn}, \mathrm{Mg}$ and $\mathrm{Co})$ in organic or inorganic forms during the pregnancy period of ewes. Abu El-Ella et al. (2014) concluded that the supplementation of BZ to basal ration at three doses $(0.0,0.5$ and $1.0 \mathrm{~g} / \mathrm{h} / \mathrm{d})$ significantly increased TP, AL and GL concentrations, and $\mathrm{A} / \mathrm{G}$ ratio during the different physiological statuses as compared with the control group. In the otherwise, the concentrations of serum $\mathrm{AL}$ of dairy cows was $(\mathrm{P}<0.05)$ increased $v s$ decreasing GL by adding two different kinds of probiotics as L. acidophilus and Bifidobactrium bifidum or Saccharomyces cerevisiae as compared to the control group during the lactation period (Mostafe et al. 2014).

\section{Blood Lipid profile:}

Parameters of serum lipid profile $(\mathrm{mg} / \mathrm{dl})$ of she-camels given different levels of BZ are presented in Table (2). Generally, the obtained data indicated that supplemented she-camels with ZB at levels 5, 7 and 10 $\mathrm{g} /$ head/day significantly or numerically improved these parameters during all the reproductive stages.

Table (2): Serum lipid profile ( $\mathrm{mg} / \mathrm{dl}$ ) of she-camels fed ration containing different levels of biogen zinc $^{\circledR}$.

\begin{tabular}{|c|c|c|c|c|c|c|}
\hline \multirow{2}{*}{ Item } & \multicolumn{4}{|c|}{ Biogen-Zn ${ }^{\circledR}$ level (g/head/day) } & \multirow{2}{*}{ SEM } & \multirow{2}{*}{$P$ value } \\
\hline & 0 & 5 & 7 & 10 & & \\
\hline \multicolumn{7}{|l|}{ Total Cholesterol } \\
\hline $10^{\text {th }}$ month of pregnancy & 69.99 & 70.54 & 58.87 & 59.24 & 1.1 & 0.1294 \\
\hline $1^{\text {st }}$ day after calving & $65.66^{\mathrm{a}}$ & $50.39^{\mathrm{b}}$ & $52.77^{\mathrm{b}}$ & $50.48^{\mathrm{b}}$ & 1.05 & 0.0012 \\
\hline $1^{\text {st }}$ month post-partum & 61.96 & 58.98 & 58.35 & 57.47 & 3.49 & 0.0781 \\
\hline During lactation period & 64.07 & 59.78 & 59.62 & 59.23 & 1.16 & 0.1012 \\
\hline \multicolumn{7}{|l|}{ Triglycerides } \\
\hline $10^{\mathrm{th}}$ month of pregnancy & 44.05 & 41.50 & 43.95 & 43.50 & 0.84 & 0.1881 \\
\hline $1^{\text {st }}$ day after calving & 43.68 & 43.58 & 43.90 & 41.83 & 0.84 & 0.3508 \\
\hline $1^{\text {st }}$ month post-partum & $45.00^{\mathrm{a}}$ & $40.00^{\mathrm{b}}$ & $41.00^{\mathrm{b}}$ & $40.00^{\mathrm{b}}$ & 0.01 & 0.0001 \\
\hline During lactation period & $42.75^{\mathrm{a}}$ & $37.75^{\mathrm{b}}$ & $39.50^{\mathrm{ab}}$ & $37.00^{\mathrm{b}}$ & 1.11 & 0.0193 \\
\hline \multicolumn{7}{|c|}{ High density lipoprotein (HDL) } \\
\hline $10^{\text {th }}$ month of pregnancy & 34.05 & 31.50 & 33.95 & 33.50 & 0.84 & 0.1881 \\
\hline $1^{\text {st }}$ day after calving & 33.68 & 33.58 & 33.90 & 31.83 & 0.84 & 0.3508 \\
\hline $1^{\text {st }}$ month post-partum & 34.25 & 32.50 & 33.50 & 30.77 & 0.80 & 0.0793 \\
\hline During lactation period & 33.00 & 32.75 & 32.00 & 34.50 & 1.70 & 0.7710 \\
\hline \multicolumn{7}{|c|}{ Low density lipoprotein (LDL) } \\
\hline $10^{\text {th }}$ month of pregnancy & $21.05^{\mathrm{a}}$ & $16.05^{\mathrm{b}}$ & $20.20^{\mathrm{a}}$ & $17.15^{\mathrm{b}}$ & 0.84 & 0.0042 \\
\hline $1^{\text {st }}$ day after calving & $20.68^{\mathrm{a}}$ & $18.13^{\mathrm{ab}}$ & $20.15^{\mathrm{a}}$ & $15.48^{\mathrm{b}}$ & 0.84 & 0.0047 \\
\hline $1^{\text {st }}$ month post-partum & $21.25^{\mathrm{a}}$ & $17.05^{\mathrm{bc}}$ & $19.75^{\mathrm{ab}}$ & $14.42^{\mathrm{c}}$ & 0.80 & 0.0007 \\
\hline During lactation period & 20.00 & 17.3 & 18.25 & 18.15 & 1.70 & 0.7279 \\
\hline \multicolumn{7}{|c|}{ Very low-density lipoprotein (VLDL) } \\
\hline $10^{\text {th }}$ month of pregnancy & $10.53^{\mathrm{a}}$ & $07.64^{\mathrm{c}}$ & $09.18^{\mathrm{b}}$ & $07.42^{\mathrm{c}}$ & 0.39 & 0.0004 \\
\hline $1^{\text {st }}$ day after calving & $10.34^{\mathrm{a}}$ & $08.63^{\mathrm{b}}$ & $09.16^{\mathrm{ab}}$ & $06.70^{\mathrm{c}}$ & 0.38 & 0.0003 \\
\hline $1^{\text {st }}$ month post-partum & $10.63^{\mathrm{a}}$ & $08.12^{\mathrm{b}}$ & $08.98^{\mathrm{b}}$ & $06.24^{\mathrm{c}}$ & 0.38 & 0.0001 \\
\hline During lactation period & 10.00 & 8.24 & 8.30 & 7.86 & 0.79 & 0.2743 \\
\hline
\end{tabular}

Means in the same row not sharing the same superscript differ significantly.

Results in Table (2) indicated that all levels of BZ significantly $(\mathrm{P}<0.05)$ decreased blood serum 
cholesterol only at $1^{\text {st }}$ day after calving. Also, added she-camels with different levels of BZ resulted in significant decrease in serum triglycerides during lactation period and at $1^{\text {st }}$ month post-partum. Similar observation was reported by; Turk (2013) who stated that serum triglycerides level was gradually increased at last month of gestation while after two months of parturition was downward. The present results disagreed with Zeedan et al. (2009b) who reported that diets of lactating buffaloes including BZ led to increase blood triglyceride during late pregnancy and postpartum periods. Antunovic et al. (2011) and Deghnouche et al. (2013) found higher concentration of triglyceride in the blood of ewes during pregnancy of ewes explained the importance of heavy transport of the lipoproteins or to energy deficiency in the meal. Also, Abu El-Ella et al. (2014) and Zeedan et al. (2014) found that addition different levels of BZ for Damascus does caused $(\mathrm{P}<0.05)$ an increase in serum cholesterol and triglyceride during pregnancy and lactation periods when compared with those of control animals. Ivan et al. (2016) suggested that cholesterol and triglycerides concentrations were upward during the late month of gestation than that at early gestation.

The addition of BZ did not affect HDL, however, LDL and VLDL were significantly $(\mathrm{P}<0.05)$ decreased by $\mathrm{BZ}$ addition at $10^{\text {th }}$ month of pregnancy and $1^{\text {st }}$ month post-partum and $1^{\text {st }}$ day after calving compared with the control group. However, LDL was higher by the addition of $7 \mathrm{~g} / \mathrm{h} / \mathrm{d}$ of BZ at $10^{\text {th }}$ day of pregnancy and $1^{\text {st }}$ day after calving as well as the control group. The increase of cholesterol concentration during pregnancy period and thereafter tend to decrease discussed by Juma et al. (2009) who suggested That may be associated with greater progesterone synthesis in the placenta (Lin et al., 1977). Then the concentration of cholesterol declines after parturition as a response of estrogen that decreased plasma LDL (Ganog, 1995).

\section{Kidney and liver functions:}

It is well known that concentrations of both Bun and creatinine in one hand, and activities of AST, ALT and ALP in other hand are good indicators for kidney and liver functions, respectively as confirmed by many workers. These biological markers are given in Table (3).

Table (3): Biological markers of Kidney and liver function in she-camels fed rations containing different levels of Biogen- $\mathrm{Zn}^{\circledR}$ at different reproductive stages.

\begin{tabular}{|c|c|c|c|c|c|c|}
\hline \multirow{2}{*}{ Item } & \multicolumn{4}{|c|}{ Biogen-Zn ${ }^{\circledR}$ level (g/head/day) } & \multirow{2}{*}{ SEM } & \multirow{2}{*}{$P$ value } \\
\hline & 0 & 5 & 7 & 10 & & \\
\hline \multicolumn{7}{|c|}{ Serum blood urea nitrogen $(\mathrm{mg} / \mathrm{dl})$} \\
\hline $10^{\text {th }}$ month of pregnancy & 14.85 & 14.30 & 14.02 & 13.59 & 0.67 & 0.7459 \\
\hline $1^{\text {st }}$ day after calving & 11.28 & 11.75 & 11.28 & 11.99 & 0.30 & 0.3142 \\
\hline $1^{\text {st }}$ month post-partum & 11.80 & 11.20 & 11.80 & 11.20 & 0.26 & 0.3236 \\
\hline During lactation period & $10.74^{\mathrm{b}}$ & $11.99^{\mathrm{a}}$ & $10.73^{\mathrm{b}}$ & $11.98^{\mathrm{a}}$ & 0.30 & 0.0123 \\
\hline \multicolumn{7}{|l|}{ Creatinine (mg/dl) } \\
\hline $10^{\text {th }}$ month of pregnancy & 01.89 & 01.88 & 01.35 & 01.51 & 0.17 & 0.1625 \\
\hline $1^{\text {st }}$ day after calving & $01.57^{\mathrm{a}}$ & $01.30^{\mathrm{b}}$ & $01.17^{\mathrm{b}}$ & $01.26^{\mathrm{b}}$ & 0.07 & 0.0288 \\
\hline $1^{\text {st }}$ month post-partum & $01.43^{\mathrm{a}}$ & $01.17^{\mathrm{b}}$ & $01.13^{\mathrm{b}}$ & $01.17^{\mathrm{b}}$ & 0.06 & 0.0336 \\
\hline During lactation period & $01.16^{\mathrm{b}}$ & $01.13^{\mathrm{b}}$ & $01.06^{\mathrm{b}}$ & $01.30^{\mathrm{a}}$ & 0.03 & 0.0019 \\
\hline \multicolumn{7}{|c|}{ Alkaline phosphatase (IU/L) } \\
\hline $10^{\text {th }}$ month of pregnancy & $61.35^{\mathrm{a}}$ & $45.44^{\mathrm{b}}$ & $37.88^{\mathrm{b}}$ & $38.13^{\mathrm{b}}$ & 2.06 & 0.0001 \\
\hline $1^{\text {st }}$ day after calving & $62.00^{\mathrm{a}}$ & $45.39^{\mathrm{b}}$ & $40.91^{\mathrm{c}}$ & $35.83^{\mathrm{d}}$ & 0.96 & 0.0001 \\
\hline $1^{\text {st }}$ month post-partum & $54.69^{\mathrm{a}}$ & $48.31^{\mathrm{b}}$ & $38.75^{\mathrm{c}}$ & $38.25^{\mathrm{d}}$ & 3.52 & 0.0415 \\
\hline During lactation period & $57.11^{\mathrm{a}}$ & $46.14^{\mathrm{b}}$ & $38.46^{\mathrm{c}}$ & $35.62^{\mathrm{d}}$ & 1.04 & 0.0001 \\
\hline \multicolumn{7}{|c|}{ Aspartate aminotransferase (IU/L) } \\
\hline $10^{\text {th }}$ month of pregnancy & 60.20 & 61.82 & 60.21 & 67.25 & 2.10 & 0.4987 \\
\hline $1^{\text {st }}$ day after calving & 51.61 & 56.88 & 60.72 & 60.13 & 2.19 & 0.0586 \\
\hline $1^{\text {st }}$ month post-partum & 52.22 & 64.69 & 57.23 & 59.89 & 3.07 & 0.0939 \\
\hline During lactation period & $55.83^{\mathrm{b}}$ & $59.57^{\mathrm{b}}$ & $73.05^{\mathrm{a}}$ & $60.16^{\mathrm{b}}$ & 2.19 & 0.0009 \\
\hline \multicolumn{7}{|c|}{ Alanine aminotransferase (IU/L) } \\
\hline $10^{\text {th }}$ month of pregnancy & 15.68 & 14.60 & 15.50 & 15.58 & 0.73 & 0.7622 \\
\hline $1^{\text {st }}$ day after calving & 12.88 & 13.13 & 10.47 & 10.00 & 0.86 & 0.0558 \\
\hline $1^{\text {st }}$ month post-partum & $12.72^{\mathrm{a}}$ & $11.41^{\mathrm{b}}$ & $10.74^{\mathrm{b}}$ & $9.47^{\mathrm{c}}$ & 0.32 & 0.0001 \\
\hline During lactation period & 11.33 & 10.78 & 09.43 & 10.27 & 0.68 & 0.4338 \\
\hline
\end{tabular}

Means in the same row not sharing the same superscript differ significantly. 
The current results showed that the addition of BZ significantly $(\mathrm{P}<0.05)$ decreased creatinine concentration at 1 st day after calving and at $1^{\text {st }}$ month post-partum compared to the control group. However, the addition of BZ didn't affect BUN concentration compared to the control group. In parallel with the present findings, Zeedan et al. (2014) showed that addition of BZ significantly decreased plasma urea and creatinine concentration of goats as compared with non-supplemented group. This result may indicate the enhancement of kidney function with BZ addition

In the current study, the activity of serum ALP recorded the lowest value by addition BZ during different stages of the experimental periods compared to the control group. Moreover, the mean value of ALP activity was 35.62- $62.0 \mathrm{IU} / 1$. The present results are supported by Al-Zamely (2011) who reported that the normal concentration of serum ALP in camel is ranged from 60 to $140 \mathrm{IU} /$ Liter. However, NRC (2001) recommended that using ALP activity is not a suitable indicator of $\mathrm{Zn}$ concentration in the animal body. Moreover, the current findings indicated that AST activity was $(\mathrm{P}=0.0009)$ higher during lactation period by addition $7 \mathrm{~g}$ of $\mathrm{BZ}$ in camels ration as compared with control group. At the same manner, Abu El-Ella et al. (2014) who found that activity of AST affected $(\mathrm{P}<0.05)$ by BZ addition in Damascus goat does during different physiological stages. However, Tharwat et al. (2015) reported that AST activity was raised in 3 weeks after birth as compared to last 3 weeks before parturition in camels in camels.

The present results demonstrated that ALT activity didn't affect by addition different levels of BZ, except at $1^{\text {st }}$ month post-partum, ALT activity tend to decrease $(\mathrm{P}=0.0001)$ with increasing the dose of $\mathrm{BZ}$ versus the control group. This was proved by, Zeedan et al. (2008 and 2009a) who reported that values of serum AST and ALT didn't affect by BZ supplementation. The present study revealed that the values of serum AST were relatively higher, whereas, the values of serum ALT were lower than the normal range attained in previous studies on she-camels. This difference may due to several reasons such as feeding, genetics differences, stress, age, liver activity and body weight (Talha et al., 2009).

\section{Live body weight:}

Results presented in Table (4) showed the effect of given she-camels $\mathrm{BZ}$ on live body weight (LBW) and feed consumption of camel in different periods.

Table (4): Productive traits of she-camels with calves given diets including different levels of Biogen$\mathbf{Z n}^{\circledR}$.

\begin{tabular}{|c|c|c|c|c|c|c|}
\hline \multirow{2}{*}{ Item } & \multicolumn{4}{|c|}{ Biogen-Zn ${ }^{\circledR}$ level (g/head/day) } & \multirow{2}{*}{ SEM } & \multirow{2}{*}{$\begin{array}{c}P \\
\text { value }\end{array}$} \\
\hline & 0 & 5 & 7 & 10 & & \\
\hline \multicolumn{7}{|l|}{ Average body weight (Kg) } \\
\hline $10^{\text {th }}$ month of pregnancy & 564.00 & 518.50 & 467.50 & 529.85 & 55.13 & 0.07 \\
\hline $1^{\text {st }}$ day after calving & $532.8^{\mathrm{a}}$ & $469.3^{\mathrm{ab}}$ & $424.5^{\mathrm{b}}$ & $482.0^{\mathrm{ab}}$ & 53.15 & 0.05 \\
\hline $1^{\text {st }}$ month post-partum & $508.8^{\mathrm{a}}$ & $467.3^{\mathrm{ab}}$ & $419.3^{\mathrm{b}}$ & $469.0^{\mathrm{ab}}$ & 43.22 & 0.04 \\
\hline During lactation period & 501.00 & 468.80 & 424.60 & 468.50 & 38.49 & 0.36 \\
\hline \multicolumn{7}{|c|}{ Average daily feed intake $(\mathrm{Kg})$ during $10^{\text {th }}$ month of pregnancy } \\
\hline Concentrate feed mixture & $7.55^{\mathrm{a}}$ & $6.48^{\mathrm{ab}}$ & $5.84^{\mathrm{b}}$ & $6.62^{\mathrm{ab}}$ & 0.13 & 0.05 \\
\hline Berseem hay & 4.80 & 4.81 & 5.00 & 4.90 & 0.08 & 0.31 \\
\hline Rice straw & 5.20 & 5.23 & 5.19 & 5.22 & 0.11 & 0.33 \\
\hline \multicolumn{7}{|c|}{ Average daily feed intake $(\mathrm{Kg})$ during one-month post-partum } \\
\hline Concentrate feed mixture & $6.66^{\mathrm{a}}$ & $5.87^{\mathrm{ab}}$ & $5.31^{\mathrm{b}}$ & $6.03^{\mathrm{ab}}$ & 0.15 & 0.05 \\
\hline Berseem hay & 4.90 & 4.80 & 5.00 & 5.07 & 0.09 & 0.11 \\
\hline Rice straw & 5.00 & 5.01 & 4.30 & 5.10 & 0.12 & 0.09 \\
\hline \multicolumn{7}{|c|}{ Average daily feed intake $(\mathrm{Kg})$ during lactation period } \\
\hline Concentrate feed mixture & 5.86 & 5.61 & 4.84 & 5.65 & 0.29 & 0.41 \\
\hline Berseem hay & $4.55^{\mathrm{b}}$ & $5.00^{\mathrm{a}}$ & $5.10^{\mathrm{a}}$ & $5.30^{\mathrm{a}}$ & 0.17 & 0.05 \\
\hline Rice straw & $4.76^{\mathrm{b}}$ & $4.90^{\mathrm{ab}}$ & $5.10^{\mathrm{a}}$ & $5.29^{\mathrm{a}}$ & 0.23 & 0.04 \\
\hline
\end{tabular}

Means in the same row not sharing the same superscript differ significantly.

The current results showed that the addition of BZ didn't improve LBW and feed intake. However, BZ at dose of $7 \mathrm{~g} / \mathrm{h} / \mathrm{d}$ decreased live body weight at $1^{\text {st }}$ day after calving and one month of post-partum versus control group. The same trends were observed in feed intake of concentrate feed mixture at month of preand post-partum. While, the intake of berseem hay and rice straw were significantly $(\mathrm{P}<0.05)$ higher than the 
control group during the lactation period.

The present results agreed with Mostafa et al. (2019) who showed that ingestion different doses of ZnMet didn't affect live body weight and feed consumption during pre- or post-partum of she-camels. In the present study, there were improvements in BH and RS consumption during lactation periods may be referring to the existence of probiotic Bacillus subtilis incorporated in BZ. This probiotic stimulates the growth of certain types of rumen microbes and hence fiber digestion (Chademana and Offer, 1990).

\section{Reproductive traits:}

Data presented in Table (5) revealed to the reproductive traits of she-camels supplemented with BZ. The results indicated that body weight at $1^{\text {st }}$ service of camels supplemented $7 \mathrm{~g}$ of $\mathrm{BZ}$ was significantly $(\mathrm{P}<0.05)$ heavier than the treated and control groups. The current results were parallel with Mostafa et al. (2019) who found that body weight of she-camels before or after calving didn't affect by Zn-Met supplementation. It is noteworthy that camels supplemented with $10 \mathrm{~g}$ of BZ showed the least number of services/ conceptions, shortest service period length and highest conception rates as compared to other groups. These findings indicated that feeding ration including BZ had positive effects on reproductive performance of camels during the post-partum period

Table (5): Reproductive traits of She-camel given different levels of Biogen- $\mathrm{Zn}^{\circledR}$ during post-partum period.

\begin{tabular}{|c|c|c|c|c|c|c|}
\hline \multirow[t]{2}{*}{ Item } & \multicolumn{3}{|c|}{ Biogen- $\mathrm{Zn}^{\circledR}$ level (g/head/day) } & & \multirow[t]{2}{*}{ SEM } & \multirow{2}{*}{$\begin{array}{l}P \\
\text { value }\end{array}$} \\
\hline & 0 & 5 & 7 & 10 & & \\
\hline Body weight at first service $(\mathrm{kg})$ & $471.6^{b}$ & $490.4^{b}$ & $529.5^{\mathrm{a}}$ & $465.3^{b}$ & 14.97 & 0.001 \\
\hline No. of services/ conception & $3.38^{\mathrm{a}}$ & $2.38^{\mathrm{b}}$ & $2.38^{\mathrm{b}}$ & $2.25^{\mathrm{b}}$ & 0.14 & 0.002 \\
\hline Service period length (day) & $18.90^{\mathrm{a}}$ & $16.88^{\mathrm{b}}$ & $16.38^{\mathrm{b}}$ & $15.88^{\mathrm{b}}$ & 0.51 & 0.043 \\
\hline Conception rate $(\%)$ & 33.30 & 66.60 & 66.30 & 100.0 & & \\
\hline \multicolumn{7}{|l|}{ Gestation and placental characteristics } \\
\hline Gestation period (day) & 381.70 & 383.00 & 382.90 & 381.90 & 0.97 & 0.601 \\
\hline Placental drop (min) & $178.95^{\mathrm{a}}$ & $170.63^{\mathrm{b}}$ & $173.38^{\mathrm{b}}$ & $164.10^{\mathrm{c}}$ & 2.14 & 0.002 \\
\hline Placental weight with fluids $(\mathrm{kg})$ & $10.71^{\mathrm{b}}$ & $11.15^{\mathrm{a}}$ & $11.91^{\mathrm{a}}$ & $12.19^{\mathrm{a}}$ & 0.15 & 0.043 \\
\hline $\begin{array}{l}\text { Placenta weight without fluids } \\
\text { (kg) }\end{array}$ & 3.63 & 3.76 & 3.68 & 3.78 & 0.13 & 0.551 \\
\hline
\end{tabular}

Means in the same row not sharing the same superscript differ significantly.

Similar results are recorded in cows by Mostafa et al. (2014) who showed that postpartum first service was earlier by about $22.5-25 \mathrm{~d}$, number of services conception was less by about 0.5 and 0.75 and days open were shorter by about 21.0 and $36.5 \mathrm{~d}$ of cows fed ration including probiotic at $3 \mathrm{~g}$ of Lactobacillus and Bifidobacterium, and $20 \mathrm{~g}$ of commercial yeast culture (S. cerevisiae), respectively as compared with the control group. The gestation periods in the present study are within the normal range as well as Mostafa $e t$ al. (2016) who stated that pregnancy lasts from 12 to 13 months in the dromedary camel. However, in the present results, there were no differences in gestation period length of camels.

Moreover, addition of different doses of BZ showed significant effect on placental characteristics, whereas the camels treated with $10 \mathrm{~g}$ of BZ showed a significant shorter duration of placental drop and heavier weights of the placenta with fluids. While, placental weight without fluids didn't affect by experimental treatments. These results concurred with Mostafa et al. (2019) who found that the addition of different levels of $\mathrm{Zn}$-Met caused significant reduction in days open and uterine involution interval of camels, as well as decreasing duration of placental drop and improving the first estrus post-partum. The effect of BZ on shortening the duration of placental drop may be due to the ability of zinc to improve the stability of oxytocin, besides, zinc is essential for the binding of oxytocin to its cellular receptor (Liu et al., 2005 and Avanti et al., 2013). While, the placental weight of BZ groups recorded the heaviest weight due to that zinc have ability to improve the placental vascular system (Wilson et al., 2017). 


\section{CONCLUSION}

The results of this study showed that supply she-camels with graded levels $(5,7$ and $10 \mathrm{~g} / \mathrm{h} / \mathrm{d})$ of organic zinc-binding with probiotic $\left(\right.$ Biogen- $\left.\mathrm{Zn}{ }^{\circledR}\right)$ enhanced their physiological status, reproductive traits and may be used in ameliorating the stress of transition period of camels. Also, the better findings were achieved with the level $10 \mathrm{~g} \mathrm{BZ/head/day.}$

\section{REFERENCES}

Abd El-Hamid, I. S., F. E. Younis, B. Farrag, M. A. H. El-Rayes and H. A. Shedeed (2019). Influence of organic or inorganic forms of salts rich in phosphorus, copper and zinc on reproduction, productivity and blood constituents in sheep. Australian Journal of Basic and Applied Sciences, 13(6): 14-22.

Abu El-Ella A. A., O. M. El-Malky and Kh. I. I. Zeedan (2014). Studies on using biogen - zinc on productive and reproductive performance of ruminants.1- physiological responses of damascus goat to diet supplementation with biogen-zinc. Egyptian Journal of Sheep and Goat Sciences, 9 (3): 29- 48.

Abu El-Ella, A. A. and O. F. Kommonna (2013). Reproductive performance and blood constituents of Damascus goat as affected by yeast culture supplementation. Egyptian J. of Sheep and Goats Sci., 8: 171178.

Al-Zamely, H. A. N. (2011). Oxidant-antioxidant status and some biochemical parameters in pregnant and non-pregnant Iraqi she camels, The Iraqi J. Vet. Med. 35 (2): 46 - 51.

Antunovic, Z.; J. Novoseleci; H. Sauerwnin; M. Speranda, M. Vegar and V. Pavic (2011): Blood metabolic profile and some of hormones concentration in ewes during different physiological status. Bulgarian Journal of Agricultural Science, 17 (5): 687-695.

Ashmawy Neama, A. (2015). Blood metabolic profile and certain hormones concentrations in Egyptian buffalo during different physiological states. Asian Journal of Animal and Veterinary Advances, 10 (6). 271-280.

Avanti, C., W. L. Hinrichs, A. Casini, A. C. Eissens, A. V. Dam, A. Kedrov, A. J. Driessen, H. W. Frijlink and H. P. Permentier (2013): The formation of oxytocin dimers is suppressed by the zinc- aspartateoxytocin complex. J Pharm Sci., 102(6):1734-1741.

Bell, A. W. (1995). Regulation of organic nutrient metabolism during transition from late pregnancy to early lactation. J. Animal. Sci., 73: 2804-2819.

Bernabucci, U., Ronchi, B., Lacetera, N. and A .Nardone (2002). Markers of oxidative status in plasma and erythrocytes of transition cows during hot season. J. Dairy Sci., 85:2173-2179.

Chademana, I. and N. W. Offer (1990). The effect of dietary inclusion of yeast culture on digestion in the sheep. Animal Science, 50(3). 483-489.

Deghnouche, K.; M. Tlidjane; T. Meziane and A. Touabti (2013): Influence of physiological stage and parity on energy, nitrogen and mineral metabolism parameters in the Ouled Djellal sheep in the Algerian Southeast arid area. African J. Agric. Res. 8 (18): pp 1920-1924.

Duncan, D.B. (1995). Multiple range and multiple F-tests. Biometrics. 11(1). 1-42.

Ganog, W.F. (1995). Review of Medical Physiology. $17^{\text {th }}$ ed: Lang Medical Publication, Los Altos California. USA: 12.

Haase, H., and L.Rink (2014). Multiple impacts of zinc on immune function. Metallomics, 6(7), 1175-1180.

Ivan F., Romana T., Dražen Đ., Silvijo V., Zlata F.-M., Przemysłav S., Martina L., Hrvoje V. and S. Marko (2016). The effect of parity on metabolic profile and resumption of ovarian cyclicity in dairy cows. Veterinarski Arhiv 86 (5), pp 641-653.

Larson C. K. (2005). Role of Trace Minerals in Animal Reproduction. Nutrition Conference - Extension and University Professional and Personal development. Dept Animal Sciences. University of Tennessee. 


\section{Morshedy et al.}

Liu D, A.B. Seuthe, O.T. Ehrler, X. Zhang, T. Wyttenbach, J.F. Hsu and M.T. Bowers (2005). Oxytocin receptor binding: why divalent metals are essential. J Am Chem Soc., 127(7):2024- 2025.

Mistry, H. D. and P. J. Williams, (2011). The importance of antioxidant micronutrients in pregnancy. Oxidative Medicine and CellularLongevity, 2011.

Mostafa, T.H., A.M. Abd El-Salaam, E. Mona, Farag and M.M. Refaei (2016). Effect of feeding treatments on productive and reproductive performance of she-camels. Global Advanced Research Journal of Agricultural Science, Vol 5(7): 263-276.

Mostafa, T.H., A. A. Bakr and M .S. Ayyat (2019). Reproductive and productive efficiency of Maghrebi dairy she-camels fed diets supplemented with zinc-methionine Biological trace element research, 1-10. https://doi.org/10.1007/s12011-019-01744-0.

Mostafa, T.H., F.A. Elsayed, M.A. Ahmed and M.A. Elkholany (2014). Effect of using some feed additives (tw- probiotics) in dairy cow rations on production and reproductive performance. Egyptian J. Anim. Prod., 51(1).1-11.

Nockels, C. J. DeBonis and J. Torrent (1993). Stress induction affects copper and zinc balance in calves fed organic and inorganic copper and zinc sources. J Anim Sci 71(9).2539-2545.

NRC (2001). Nutrient requirement of dairy cattle, 7th Rev. ed. National Academy Press, Washington, 401 p.

Paripatananont, T. and R. T. Lovell (1997). Comparative net absorption of chelated and inorganic trace minerals in channel catfish Ictalurus punctatus diets. Journal of the World Aquaculture Society, 28(1), 62-67.

Patel, B., N.Kumar, V.Jain, N. Raheja, S.K.Yadav, N.Kumar and S.V. Singh (2017). Effect of zinc supplementation on hormonal and lipid peroxidation status of peri-parturient Karan Fries cows during heat stress condition. Indian J. Anim. Res., 3356, 1-5.

Salama, A. A. K., X. Such, G. Caja, M. Rovai, R. Casals, E. Albanell and A. Marti (2003). Effects of once versus twice daily milking throughout lactation on milk yield and milk composition in dairy goats. Journal of dairy science, 86(5), 1673-1680.

SAS (2001). SAS/STAT User's Guide. Version 6, 5th (Ed.), SAS Institute Inc., Cary, NC.

Seleim, R.S., A. R. Tos., S. R. Mohamed, H.S. Nada and R.A. Gobran (2003). ELISA and other tests in the diagnosis of Pasterella multocida in camels. http://www.priory.com/vet/camel.htm (accessed November 2015).

Shams, A.S. (2008). Utilization of zinc methionine supplementation on milk production and somatic cell count in Friesian cows. M.Sc. Thesis. Anim. Prod. Dept. Kafr El-Sheikh.

Soetan, K. O., C. O. Olaiya and O. E. Oyewole (2010). The importance of mineral elements for humans, domestic animals and plants-A review. African J. Food Sci., 4(5): 200-222.

Spears, J. (1989). Zinc methionine for ruminants: relative bioavailability of zinc in lambs and effects of growth and performance of growing heifers. J Anim Sci 67(3):835-843.

Talha, M. H., R. I. Moawd, A. A. Abu El-Ella and G. H. Zaza (2009). Effect of some feed additive on rearing calves from birth to weaning: 1- Productive performance and some blood parameters. J. Agric. Sci. Mansoura Univ., 34: 2611-2631.

Tharwat, M., A. Ali, F. Al-Sobayil, L. Selim and H. Abbas,(2015). Hematobiochemical profile in female camels (Camelus dromedarius) during the periparturient period, J. Camel Pract and Res, 22 (1): 101-6.

Turk, R., O. Podpečan, J. Mrkun, M. Kosec, Z. Flegar-Meštrić, S. Perkov, J. Starič, M. Robić, M. Belić and P. Zrimšek (2013). Lipid mobilisation and oxidative stress as metabolic adaptation processes in dairy heifers during transition period. Anim. Reprod. Sci., 141: 109-115.

Warnick, G.R., V. Benderson and N. Albers (1983). Selected Methods. Clin Chem, 10: 91-99.

Wilson, R.L., S.Y. Leemaqz, Z. Goh, D. McAninch, T.J. Karasoulos, E.G. Leghi, J. A. Phillips, K. M. Colafella, C. Tran, S. O’Leary, S. Buckberry, A.S. Pederson, S. Robertson, T. Bianco-Miotto and S. T. Roberts (2017). Zinc is a critical regulator of placental morphogenesis and maternal hemodynamics during pregnancy in mice. Sci Rep 7, 15137- 15142. doi:10.1038/s41598-017-15085-2. 
Zeedan, Kh.I.I., G.F. Shahin and S.B. Mehany (2009a). Using of biogen-zinc supplementation in finishing ration of buffalo bulls on their fattening performance. Egyptian J. Nut. and feeds, 12(3).179-192.

Zeedan, Kh.I.I. O.M. El-Malky and A.A. Abu El-Ella (2014). Nutritional, physiological and microbiological studies on using biogen - zinc on productive and reproductive performance of ruminants. 2-productive performance, digestion and some blood components of damascus goats. Egyptian Journal of Sheep \& Goat Sciences, Vol. 9 (3), P: 49- 66.

Zeedan, Kh.I.I., O.M. El-Malky, and O.F. Komonna, (2009b). Productive and reproductive performance of buffaloes fed on rations supplemented with biogen-zinc at late pregnancy period. Proc. of the 2 nd Scientific Conf. of Anim. Wealth Res. in the Middle East and North Africa Cairo Inter. Convention Center, Egypt, 24 - 26 October: $237-249$.

Zeedan, Kh.I.I. O.M., El-Malky, O.F. Komonna, M.A. Abdel-Latif and E.I.M. Abouelenin (2008). Effect of biogen-zinc supplementation on some production, digestion, rumen fermentation and some blood parameters in buffalo. Egyptian J. Anim. Prod., 45: 557 -569.

جافٔه اضافة الزنك العضوى للنوق المغربيه على الخصائص البيوكيميائيه والتناسليه والانتاجيه تحت الظروف الثبه

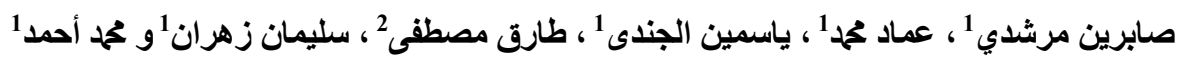

1قسم الإنتاج الحيواني والسمكي ـ كلية زراعة سابا باشا ـ جامعة الإسكندرية ـ مصر.

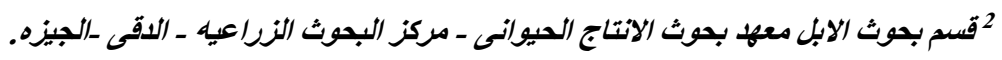

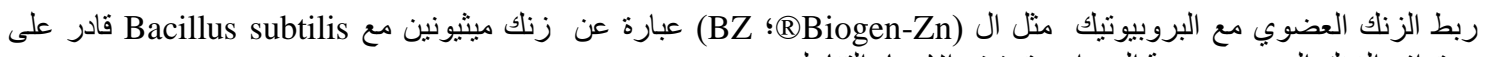
تحسين تو افر الزنك الحيوي وصحة الحيو ان وتخفيف الإجهاد التناسلي.

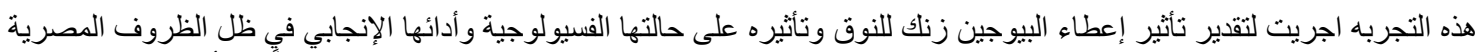

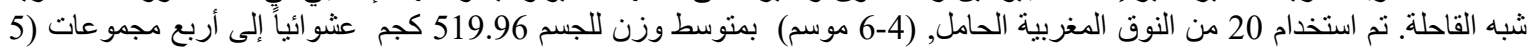

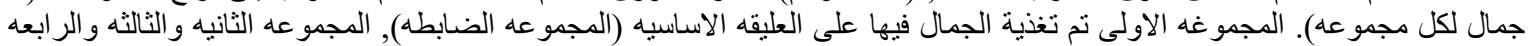

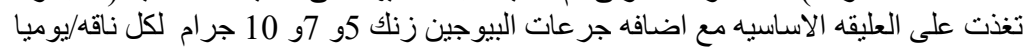

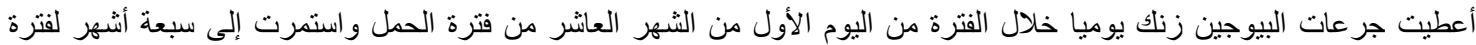

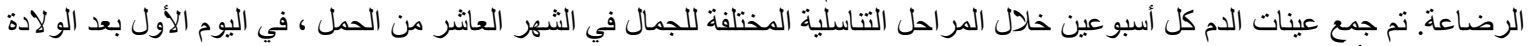
، وخلال سبعة أثثر من فترة الرضاعة الرئ.

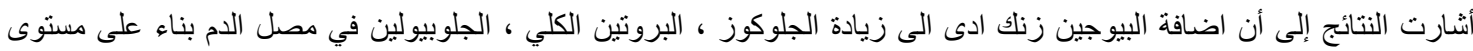

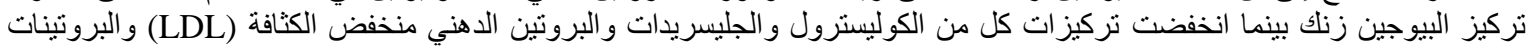

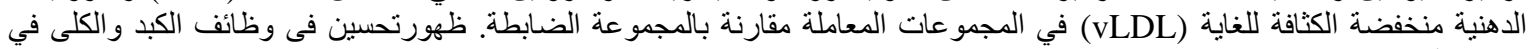

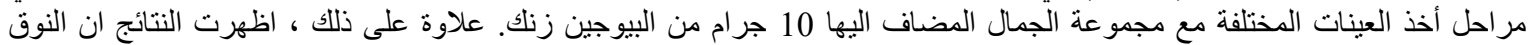

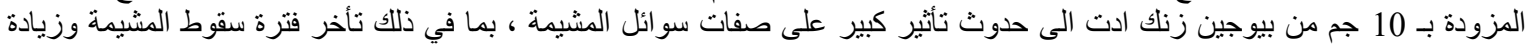

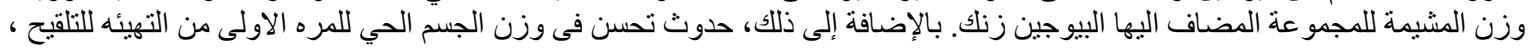

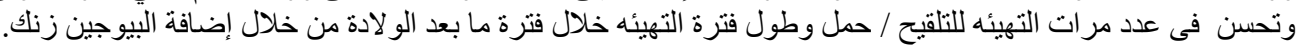

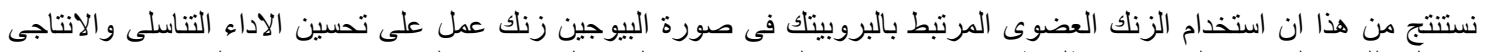

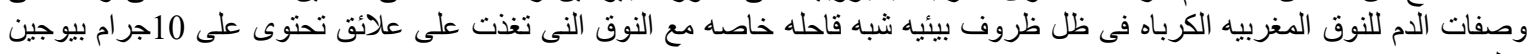

